\title{
MICROPROPAGATION OF YUCCA PLANT BY USING GUAR AND LOCUST BEAN SEED POWDER AS AN ALTERNATIVE CHEAP GELLING AGENT
}

\author{
H.M.S. Hassan ${ }^{*}$ and M. Moubarak ${ }^{* *}$ \\ * Department of Plant Production, Fac. Environ. Agric. Sci., Arish Univ., El-Arish, Egypt \\ ** Department of Horticulture, Fac. Agric., Damanhour Univ., Damanhour City, Egypt
}

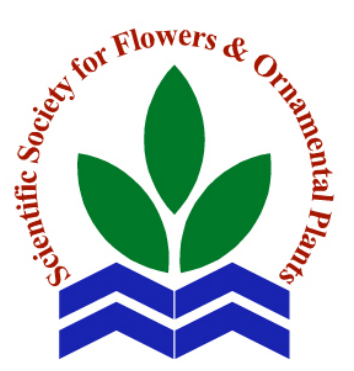

Scientific J. Flowers \& Ornamental Plants, 7(3):239-246 (2020).

Received:

11/7/2020

Accepted:

22/7/2020
ABSTRACT: The present study aims to determine the best type and concentration of growth regulators and find cheap and/or readilyavailable alternative substitutes of agar for tissue culture media preparation. The results clear that MS medium supplemented with $1 \mathrm{mg} \mathrm{l}^{-1}$ BA significantly outperformed other tested cytokinins concerning yucca shoot multiplication and growth parameters [number of shoots/explant, number of leaves/shoot, and shoot length $(\mathrm{cm})]$ which recorded 4.75, 14.00 and $6.50 \mathrm{~cm}$, respectively. Moreover, the combination between $2 \mathrm{~g} \mathrm{l}^{-1}$ agar and $6 \mathrm{~g} \mathrm{l}^{-1}$ guar as gelling agents produced the maximum shoot growth values. During rooting stage, data clear that $1.0 \mathrm{mg} \mathrm{l}^{-1} \mathrm{NAA}$ increased number of leaves/shoot, number of roots/shoot and root length with mean values of 20.50, 3.75 and $5.22 \mathrm{~cm}$, respectively. Finally, rooted plantlets were successfully acclimatized with maximum survivability percentage (100\%) in soil mixture of sand and peat moss $(1: 1 . \mathrm{v} / \mathrm{v})$.

Key words: Yucca, BA, gelling agent, guar seeds powder, NAA.

\section{INTRODUCTION}

Yucca (Yucca elephantipes L.) is an evergreen and monocotyledonous plant, which belongs to family Agavaceae. It is of paramount interest of garden landscaping in arid and semi-arid regions for its outstanding ability to grow under such hostile conditions. Moreover, Yucca is considered as a popular plant for indoor decoration (Navin et al., 1992).

However, yucca propagation via cuttings and offsets produces few plants. On the other hand, micropropagation offers major production and marketing advantages over traditional propagation methods.

Therefore, the current work was conducted to establish rapid procedure for in vitro multiplication, rooting and acclimatization, and hence facilitate the release of the used yucca genotypes at large scale production (Elshafei et al., 2011).

In the same time, agar has remained to be the most frequently used gelling agent for both plants and microbes culture media. Many advances of agar make it a gelling agent of choice such as, stability, high clarity, non-toxic nature and resistance to metabolism during culture (McLachlan, 1985 and Henderson and Kinnersley, 1988).

However, some doubts have been raised about its suitability. In addition, overexploitation of its limited resources and prohibitive prices are other reasons that propel attempts to identify another MS medium suitable gelling agent substitutes.

Guar seed powder is endospermsderived from Cyamopsis tetragonoloba. Its gum has a water-soluble fraction (85\%) named guaran. This compound is a non-toxic polysaccharide made up of straight chain 
mannan, with relatively regular branching of every second mannose by a single galactose unit (Windholz et al., 1983).

Guar gum and seed powder have been used as gelling agent in many plants tissue culture media such as Hassan et al. (2016) on Philodendron selloum.

However, the highest multiplication rate was achieved on medium gelled with plant agar, plantlets grown on medium solidified by guar gum were extremely vigorous and well developed (Fira et al., 2010).

Combination of agar and guar increased the number of regenerated shoots in micropropagation of pear (Pyrus communis L., 'Durondeau'), in vitro seed germination of Linum usitatissimum, Brassica juncea, in vitro axillary shoot proliferation in nodal explants of Crataeva nurvala and rooting of regenerated shoots of these plants compared to media solidified by agar (Babbar et al., 2005 and Lucyszyn et al., 2006).

Locust bean (LB) also known as carob seeds of leguminous plant Ceratonia siliqua Linn (Leguminosae) were used as gelling agent for shoot multiplication and rooting of carob tree. The obtained results show that locust bean gum can be used in combination with agar in culture medium as a gelling agent without negative effect on plant material and with the advantage of reduced medium costs (Romano and Goncalves, 2005). Also, Hassan et al. (2016) on Philodendron selloum found that locust bean (LB) at $4 \mathrm{~g} \mathrm{l}^{-1}$ as gelling agent produced the maximum growth values. However, Soliman et al. (2016) on Codiaeum varigatum reported that $4 \mathrm{gl}^{-1}$ agar $+4 \mathrm{gl}^{-1} \mathrm{LB}$ gave the maximum values of shoot proliferation and growth.

The present study was designed to investigate the effect of different growth regulators and different inexpensive gelling agent alternatives combinations with agar on micropropagation of Yucca elephantipes L.

\section{MATERIALS AND METHODS}

This study was carried out in Prof. Dr. Abd El-Fatah Helmy Belal Plant Tissue Culture Laboratory, Faculty of Environ. Agric. Sci., Arish University, from April 2017 to September 2018 to improve micropropagation of yucca (Yucca elephantipes L.) by using inexpensive and easily available substitutes of agar that could be utilized for preparing tissue culture media.

\section{Establishment stage:}

\section{Plant material and explant sterilization:}

Axillary buds and shoot tips were excised from Yucca elephantipes L. plants grown in greenhouses of Experimental Farm, Fac. of Environ. Agric. Sci., Arish University, El-Arish, North Sinai. Explants were surface sterilized by soaking in $0.1 \%$ mercuric chloride solution for $5 \mathrm{~min}$, then soaked in Clorox solution $(\mathrm{NaOCl}, 5.25 \%$ free chlorine) at concentration of $20 \%$ for 10 min. Explants were thoroughly rinsed three times with sterile distilled water after each previous step.

The sterilized explants were cultured on MS medium Murashige and Skoog (1962) with $30 \mathrm{~g} \mathrm{l}^{-1}$ sucrose and supplemented with three different cytokinin types namely benzyl adenine (BA), kinetin (kin) or 2isopentenyladenine (2ip) at $1 \mathrm{~m} \mathrm{gl}^{-1}$ to choose the best cytokinin type for yucca micropropagation. Number of shoots/ explant, number of leaves/shoot and shoot length $(\mathrm{cm})$ data were recorded after 6 weeks from inoculation date. The medium $\mathrm{pH}$ was adjusted at 5.7-5.8 and solidified with $8 \mathrm{~g} \mathrm{l}^{-1}$ agar. Medium was distributed into glass jars $(60 \times 120 \mathrm{~mm})$ every jar contained about 50 $\mathrm{ml}$ medium, finally jars were sterilized in autoclave at $121{ }^{\circ} \mathrm{C}$ and $1.1 \mathrm{~kg} / \mathrm{cm}^{2}$ for 20 min.

\section{Multiplication stage:}

Axillary shoots and shoot tips (about 1.5- $2.0 \mathrm{~cm}$ length) obtained from previous stage were transferred to MS medium contained BA (the best cytokinin for shoot 
induction) at $0.5,1.0,1.5$ or $2.0 \mathrm{mg} \mathrm{l}^{-1}$. Number of shoots/explant, number of leaves/shoot and shoot length $(\mathrm{cm})$ data were recorded after 6 weeks from inoculation date. The best multiplication treatment $\left(1.0 \mathrm{mg} \mathrm{l}^{-1}\right.$ BA) was repeated to obtain enough shoots for the second multiplication experiment.

The effect of alternative gelling agents during multiplication stage:

This experiment was conducted to determine the influence of alternative gelling agents on shoot multiplication of Yucca elephantipes L. plants by culturing shoot tips on MS medium contained (1.0 $\mathrm{mg} \mathrm{l}^{-1} \mathrm{BA}$ ) and solidified with a combination between guar or locust bean (LB) seeds powder and agar as follows: $8 \mathrm{~g} \mathrm{l}^{-1}$ agar (as control), 6 $\mathrm{gl}^{-1}$ agar $+2 \mathrm{~g} \mathrm{l}^{-1}$ guar seed powder, $4 \mathrm{~g} \mathrm{l}^{-1}$ agar $+4 \mathrm{~g} \mathrm{l}^{-1}$ guar seed powder, $2 \mathrm{~g} \mathrm{l}^{-1}$ agar + $6 \mathrm{~g} \mathrm{l}^{-1}$ guar seed powder, $6 \mathrm{~g} \mathrm{l}^{-1}$ agar $+2 \mathrm{~g} \mathrm{l}^{-1}$ locust bean seed, $4 \mathrm{~g} \mathrm{l}^{-1}$ agar $+4 \mathrm{~g} \mathrm{l}^{-1}$ locust bean seed or $2 \mathrm{~g} \mathrm{l}^{-1}$ agar $+6 \mathrm{~g} \mathrm{l}^{-1}$ locust bean seed.

\section{Rooting stage:}

\section{Effect of different auxin types at $1 \mathrm{mg} \mathrm{l}^{-1}$ on yucca plants rooting:}

Shoots (about $2 \mathrm{~cm}$ length) obtained from the second multiplication experiment were cultured on MS medium without growth regulators for 4 weeks then shoots (about $3 \mathrm{~cm}$ ) were cultured on MS medium supplemented with indol acetic acid (IAA), naphthalene acetic acid (NAA) or indol buteric acid (IBA) at $1.0 \mathrm{mg} \mathrm{l}^{-1}$. After 4 weeks from inculation, the following data were recorded; plantlet length $(\mathrm{cm})$, number of leaves/plantlet, number of roots and root length $(\mathrm{cm})$.

\section{Effect of different naphthalene acetic acid (NAA) concentrations on yucca shoot rooting:}

Previous experiment results indicated that naphthalene acetic acid (NAA) recorded the best results of rooting so that, shoots obtained from multiplication stage were cultured on MS media supplemented with naphthalene acetic acid (NAA) at 0.0, 0.5,
1.0, 1.5 or $2 \mathrm{mg} \mathrm{l}^{-1}$. The abovementioned data were recorded after 4 weeks.

\section{Acclimatization stage:}

Well rooted plantlets were transferred into (8 cm diameter) plastic pots containing a mixture of sand and peat moss at equal volumes. To keep a high relative humidity around the plantlets, polyethylene bags were employed to cover the pots. Pots were kept in greenhouse. Ten days later, small holes were poked in the plastic covers to facilitate air circulation. After additional 10 days, relative humidity was gradually reduced, and the covers were completely removed. After 4 weeks survivability percentage was determined.

\section{Culture conditions:}

Cultures of the above-mentioned in vitro experiments were incubated in growth room at $25 \pm 2{ }^{\circ} \mathrm{C}$ under $16 \mathrm{~h} /$ day photoperiod which supported with cool white fluorescent lamps with light intensity of 2000 Lux.

\section{Experimental design and statistical analysis:}

All the above-mentioned experiments design was complete randomized design (CRD). Collected data were analyzed by the analysis of variance (ANOVA) procedure using MSTAT-C Statistical Software Package (Michigan State University, 1983). Differences between means were compared by using Duncan's multiple range test (Duncan, 1955).

\section{RESULTS AND DISCUSSION}

\section{Establishment stage:}

Table (1) and Fig. (1) indicated that, using of BA significantly increased all shoot growth parameters (number of shoots/ explant, number of leaves/shoot and shoot length) of Yucca compared with control. Also, results indicated that the greatest values for these growth characters (4.75, 14.00 and $6.50 \mathrm{~cm}$, respectively) were recorded by using $1 \mathrm{mg} \mathrm{l}^{-1} \mathrm{BA}$. 
Table 1. Effect of different cytokinin types at $1 \mathrm{mg} \mathrm{l}^{-1}$ on Yucca elephantipes L. shoot growth during establishment stage.

\begin{tabular}{cccc}
\hline $\begin{array}{c}\text { Cytokinin type } \\
\text { at } \mathbf{1} \text { mg I }^{\mathbf{1}}\end{array}$ & $\begin{array}{c}\text { Number of } \\
\text { shoots/explant }\end{array}$ & $\begin{array}{c}\text { Number of leaves } \\
\text { /shoot }\end{array}$ & $\begin{array}{c}\text { Shoot length } \\
\text { (cm) }\end{array}$ \\
\hline Control & $1.00 \mathrm{~b}$ & $9.50 \mathrm{~b}$ & $2.85 \mathrm{c}$ \\
BA & $4.75 \mathrm{a}$ & $14.00 \mathrm{a}$ & $6.50 \mathrm{a}$ \\
KIN & $1.00 \mathrm{~b}$ & $13.25 \mathrm{a}$ & $4.62 \mathrm{~b}$ \\
2IP & $1.00 \mathrm{~b}$ & $9.50 \mathrm{~b}$ & $3.87 \mathrm{bc}$ \\
\hline
\end{tabular}

Means having the same letter (s) within the same column are not significantly different according to Duncan's multiple range test at $5 \%$ level of probability.

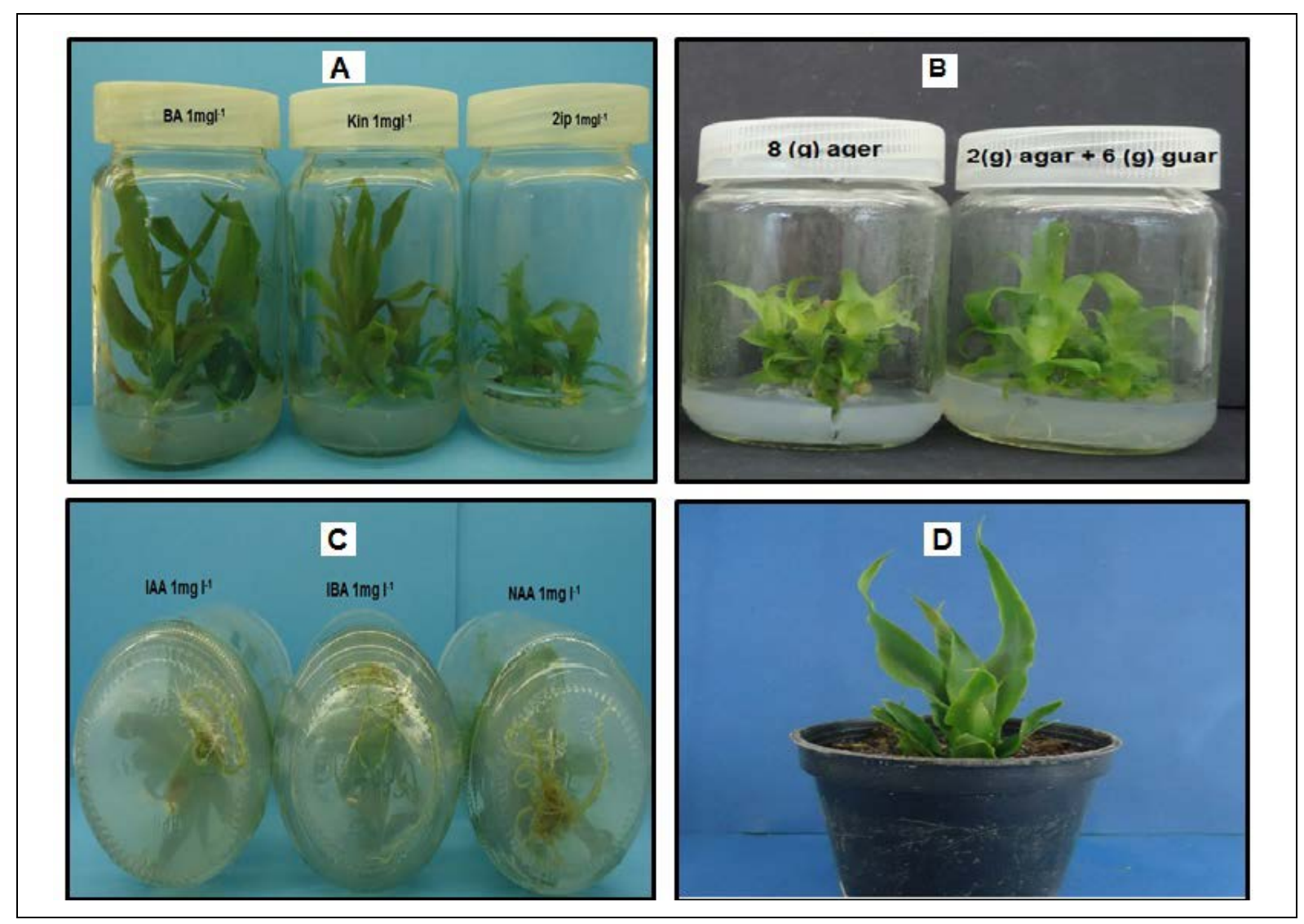

Fig. 1. Multiplication of Yucca elephantipes L., (A) Effect of cytokinin type (BA, Kin and 2ip at $1 \mathrm{mgl}^{-1}$ ) on shoot growth during establishment stage, (B) Effect of using $2 \mathrm{~g}$ agar $+6 \mathrm{~g}$ guar as gelling agents on shoot growth during multiplication stage, (C) Effect of auxin type (IAA, IBA and NAA at $1 \mathrm{mg} \mathrm{l}^{-1}$ ) on shoot and root growth during rooting stage, (D) Acclimatized $Y$. elephantipes L. plant.

These results seems to be in complies with those found by Faisal et al. (2006) when they evaluate the effect of BA, kin and 2-iP as supplements to Murashige and Skoog (MS) medium since they found that benzyladinine (BA) at an optimal concentration $(5.0 \mu \mathrm{M})$ was effective in inducing multiple shoots. Also, Khalafalla et al. (2011) on Boscia senegalensis achieved the highest number of shoots per explant on MS medium supplemented with $3 \mathrm{mg} \mathrm{l}^{-1} \mathrm{BA}$, while the 
highest shoot length was obtained with 1 mg l-1 BA.

\section{Multiplication stage:}

Effect of BA concentration on Yucca elephantipes $\mathrm{L}$. shoot growth and multiplication during multiplication stage:

The effect of BA concentration on yucca shoot growth traits were showed in Table (2). The results cleared that using MS medium supplemented with BA at $1.0 \mathrm{mg} \mathrm{l}^{-1}$ resulted in significant increase for all yucca growth parameters i.e., number of shoots/explant, number of leaves/shoot and shoot length $(\mathrm{cm})$ with mean values of 4.50 , 17.50 and $5.15 \mathrm{~cm}$, respectively. The increasing percentages resulted from using $1.0 \mathrm{mg} \mathrm{l}^{-1}$ BA over the control were estimated by $125 \%$ for number of shoots/explant, $45.83 \%$ for number of leaves/shoot and $96.56 \%$ for shoot length. It is worth to mention that there were no significant differences between 0.5 and 1.0 $\mathrm{mg} \mathrm{l}^{-1} \quad \mathrm{BA}$ concerning number of leaves/shoot and shoot length. The obtained results were in agreement with Shaheen et al. (2009) since they found that the number of developed vegetative branches of yucca culminated with BA at $2 \mathrm{mg} \mathrm{l}^{-1}$ concentration. However, zero BA did not result in any developed branches.

Effect of gelling agents on Yucca elephantipes $\mathrm{L}$. vegetative growth during multiplication stage:

The results in Table (3) indicated that the combination between $2 \mathrm{~g} \mathrm{l}^{-1}$ agar and $6 \mathrm{~g} \mathrm{l}^{-1}$ guar seed powder as gelling agent produced the maximum growth values for all yucca growth parameters i.e., number of shoots/explant, number of leaves/shoot, and shoot length $(\mathrm{cm})$, which recorded, 3.00, 16.00 and $5.66 \mathrm{~cm}$; respectively with increasing percentages estimated by $50 \%$, $33.33 \%$ and $54.22 \%$ for these parameters, respectively compared with corresponding

Table 2. Effect of BA concentration on Yucca elephantipes L. shoot growth and multiplication during multiplication stage.

\begin{tabular}{cccc}
\hline $\begin{array}{c}\text { BA concentration } \\
\left(\mathbf{m g ~ I}^{\mathbf{1}}\right)\end{array}$ & $\begin{array}{c}\text { Number of } \\
\text { shoots/explant }\end{array}$ & Number of leaves/shoot & Shoot length (cm) \\
\hline $\mathbf{0 . 0}$ (Control) & $2.00 \mathrm{~b}$ & $12.00 \mathrm{~b}$ & $2.62 \mathrm{~b}$ \\
$\mathbf{0 . 5}$ & $2.00 \mathrm{~b}$ & $17.00 \mathrm{a}$ & $4.87 \mathrm{a}$ \\
$\mathbf{1 . 0}$ & $4.50 \mathrm{a}$ & $17.50 \mathrm{a}$ & $5.15 \mathrm{a}$ \\
$\mathbf{1 . 5}$ & $3.50 \mathrm{a}$ & $12.50 \mathrm{~b}$ & $2.80 \mathrm{~b}$ \\
$\mathbf{2 . 0}$ & $3.00 \mathrm{ab}$ & $11.50 \mathrm{~b}$ & $2.30 \mathrm{~b}$ \\
\hline
\end{tabular}

Means having the same letter (s) within the same column are not significantly different according to Duncan's multiple range test at $5 \%$ level of probability.

Table 3. Effect of gelling agents on Yucca elephantipes L. shoot growth and multiplication during multiplication stage.

\begin{tabular}{cccc}
\hline $\begin{array}{c}\text { Treatments } \\
\left(\mathbf{g ~ I}^{\mathbf{1}}\right)\end{array}$ & $\begin{array}{c}\text { Number of } \\
\text { shoots/explant }\end{array}$ & Number of leaves/shoot & Shoot length (cm) \\
\hline 8 Agar (Control) & $2.00 \mathrm{a}-\mathrm{c}$ & $12.00 \mathrm{ab}$ & $3.67 \mathrm{~b}-\mathrm{d}$ \\
$\mathbf{6}$ Agar + 2 Guar & $2.00 \mathrm{a}-\mathrm{c}$ & $9.33 \mathrm{~b}$ & $3.00 \mathrm{~b}-\mathrm{d}$ \\
$\mathbf{4}$ Agar + 4 Guar & $2.67 \mathrm{ab}$ & $11.33 \mathrm{~b}$ & $4.33 \mathrm{~b}$ \\
$\mathbf{2}$ Agar + 6 Guar & $3.00 \mathrm{a}$ & $16.00 \mathrm{a}$ & $5.66 \mathrm{a}$ \\
6 Agar + 2 LB & $1.33 \mathrm{c}$ & $11.00 \mathrm{~b}$ & $2.67 \mathrm{~cd}$ \\
4 Agar + 4 LB & $2.33 \mathrm{a}-\mathrm{c}$ & $16.00 \mathrm{a}$ & $4.00 \mathrm{bc}$ \\
2 Agar + 6 LB & $1.67 \mathrm{bc}$ & $11.33 \mathrm{~b}$ & $2.33 \mathrm{~d}$ \\
\hline
\end{tabular}

LB: locust bean

Means having the same letter (s) within the same column are not significantly different according to Duncan's multiple range test at $5 \%$ level of probability. 
control mean values. However, there were no significant difference between control $\left(8 \mathrm{~g} \mathrm{l}^{-1}\right.$ agar) and this treatment $\left(2 \mathrm{gl}^{-1}\right.$ agar $+6 \mathrm{~g} \mathrm{l}^{-1}$ guar seed powder) concerning number of shoots/explant and number of leaves/shoot.

The obtained results were in the same way with those found by Abdallah et al. (2019) on Haplophyllum tuberculatum L. they obtained that Murashige and Skoog (MS) was the best medium and agar at $6 \mathrm{~g} \mathrm{l}^{-1}$ + guar seed powder at $2 \mathrm{~g} \mathrm{l}^{-1}$ was the best gelling agent treatment.

\section{Rooting stage:}

Effect of different auxin types at $1 \mathrm{mg} \mathrm{l}^{\mathbf{l}^{-1}}$ on Yucca elephantipes L. shoot growth and rooting during rooting stage:

The results presented in Table (4) and Fig. (1) show that using MS medium supplemented with NAA at $1.0 \mathrm{mg} \mathrm{l}^{-1}$ significantly increased number of leaves/shoot, number of roots/shoot and root length with mean values 20.50, 3.75 and $5.22 \mathrm{~cm}$, respectively. On the other hand, shoot length $(\mathrm{cm})$ did not significantly affect by auxin type. These results were in the same line with Moudi et al. (2014) they studied the effect of NAA concentrations on bamboo Bambusa nutans Wall. Ex. Munro rooting.they reported that $85 \%$ of rooting was recorded on $2 \mathrm{mg} \mathrm{l}^{-1} \mathrm{NAA}$.

Moreover, Abdulmalik et al. (2012) on Arachis hypogaea L. reported that rooting was significantly influenced by the presence and concentration of NAA. Microshoots subcultured on medium supplemented with 1 $\mathrm{mg} \mathrm{l}^{-1}$ NAA rooted within 2 weeks of subculture, producing the highest number of roots/plantlet and root-induction frequency.

Effect of NAA concentrations on Yucca elephantipes $\mathrm{L}$ growth during rooting stage:

The Effect of NAA concentration on yucca shoot growth and rooting during rooting stage were shown in Table (5). The results clarified that using MS medium supplemented with NAA at $1.0 \mathrm{mg} \mathrm{l}^{-1}$ resulted in significant increase for all yucca shoot and root growth parameters i.e., shoot length, number of leaves/shoot, number of roots/shoot and root length which recorded $7.77 \mathrm{~cm}, 13.50,5.25$ and $4.97 \mathrm{~cm}$, respectively. The increasing percentages of the mean values of yucca growth parameters with $1.0 \mathrm{mg} \mathrm{l}^{-1} \mathrm{NAA}$ treatment over the control were $35.13 \%$, 58.82\%, $133.33 \%$ and $86.14 \%$, respectively. These results are in a harmony with those obtained by Seyyed et al. (2013) since they studied the effect of different concentrations of NAA and BAP on micropropagation of Alstroemeria by apical and lateral bud explants. These explants were cultured on MS medium containing NAA $(0$, $0.2,0.5$ and $\left.1.0 \mathrm{mg} \mathrm{l}^{-1}\right)$ and $\operatorname{BAP}(0,0.5,1.0$, 1.5 and $\left.2.5 \mathrm{mg} \mathrm{l}^{-1}\right)$. The results showed that the highest shoot length, root length, maximum root number and bud number were recorded on culture medium containing 1.0 $\mathrm{mg} \mathrm{l}^{-1}$ NAA.

Table 4. Effect of different auxin types at $1 \mathrm{mg} \mathrm{l}^{-1}$ on Yucca elephantipes L. shoot growth and rooting during rooting stage.

\begin{tabular}{ccccc}
\hline $\begin{array}{c}\text { Auxin type } \\
\left(\mathbf{1} \mathbf{~ m g ~ I} \mathbf{~}^{-1}\right)\end{array}$ & $\begin{array}{c}\text { Shoot length } \\
\text { (cm) }\end{array}$ & $\begin{array}{c}\text { Number of leaves/ } \\
\text { shoot }\end{array}$ & $\begin{array}{c}\text { Number of } \\
\text { roots/shoot }\end{array}$ & $\begin{array}{c}\text { Root length } \\
\text { (cm) }\end{array}$ \\
\hline $\begin{array}{c}\text { Without auxin } \\
\text { (Control) }\end{array}$ & $5.90 \mathrm{a}$ & $9.00 \mathrm{~b}$ & $2.50 \mathrm{~b}$ & $2.20 \mathrm{c}$ \\
IBA & $5.95 \mathrm{a}$ & $10.00 \mathrm{~b}$ & $2.75 \mathrm{ab}$ & $3.50 \mathrm{~b}$ \\
IAA & $5.95 \mathrm{a}$ & $12.00 \mathrm{~b}$ & $2.50 \mathrm{~b}$ & $1.37 \mathrm{~d}$ \\
NAA & $6.30 \mathrm{a}$ & $20.50 \mathrm{a}$ & $3.75 \mathrm{a}$ & $5.22 \mathrm{a}$ \\
\hline
\end{tabular}

Means having the same letter (s) within the same column are not significantly different according to Duncan's multiple range test at $5 \%$ level of probability. 
Table 5. Effect of NAA concentration on Yucca elephantipes L. shoot and root growth during rooting stage.

\begin{tabular}{ccccc}
\hline $\begin{array}{c}\text { NAA concentration } \\
\left(\mathbf{m g ~ l}^{-1}\right)\end{array}$ & $\begin{array}{c}\text { Shoot length } \\
(\mathbf{c m})\end{array}$ & $\begin{array}{c}\text { Number of } \\
\text { leaves/shoot }\end{array}$ & $\begin{array}{c}\text { Number of } \\
\text { roots/shoot }\end{array}$ & $\begin{array}{c}\text { Root length } \\
(\mathbf{c m})\end{array}$ \\
\hline $\mathbf{0 . 0}$ (Control) & $5.75 \mathrm{~b}$ & $8.50 \mathrm{~b}$ & $2.25 \mathrm{~b}$ & $2.67 \mathrm{~b}$ \\
$\mathbf{0 . 5}$ & $5.75 \mathrm{~b}$ & $9.00 \mathrm{~b}$ & $2.25 \mathrm{~b}$ & $1.25 \mathrm{~cd}$ \\
$\mathbf{1 . 0}$ & $7.77 \mathrm{a}$ & $13.50 \mathrm{a}$ & $5.25 \mathrm{a}$ & $4.97 \mathrm{a}$ \\
$\mathbf{1 . 5}$ & $5.75 \mathrm{~b}$ & $10.00 \mathrm{~b}$ & $3.25 \mathrm{~b}$ & $0.95 \mathrm{~d}$ \\
$\mathbf{2 . 0}$ & $5.65 \mathrm{~b}$ & $9.00 \mathrm{~b}$ & $3.22 \mathrm{~b}$ & $1.03 \mathrm{~d}$ \\
\hline
\end{tabular}

Means having the same letter (s) within the same column are not significantly different according to Duncan's multiple range test at $5 \%$ level of probability.

\section{Acclimatization stage:}

Plantlets of Yucca elephantipes L. were successively acclimatized with maximum survivability percentage $(100 \%)$ in soil mixture of sand and peat moss $(1: 1 . \mathrm{v} / \mathrm{v})$.

\section{CONCLUSION}

From above-mentioned results, it could be concluded that for obtaining high multiplication rate and good shoot growth of Yucca elephantipes as well as lowering gelling agent cost it is recommended to use MS media fortified with $1 \mathrm{mg} \mathrm{l}^{-1} \mathrm{BA}$ and solidifying with $2 \mathrm{gl}^{-1}$ agar $+6 \mathrm{~g} \mathrm{l}^{-1}$ guar seed powder as gelling agent.

\section{REFERENCES}

Abdallah, Sonia A.S.; Ali, M.A.M.; ElMekawy, M.A. and Abd El-Hameed, M.M. (2019). Some factors affecting micropropagation of Haplophyllum tuberculatum L. Zagazig J. Agric. Res., 46(3):635- 647.

Abdulmalik, M.M.; Usman, I.S.; Olarewaju, J.D. and Aba, D.A. (2012). Effect of naphthalene acetic acid (NAA) on in vitro rooting of regenerated microshoots of groundnut (Arachis hypogaea L.). Bayero Journal of Pure and Applied Sciences, 5(2):128-131.

Babbar, S.B.; Jain, R. and Walla, N. (2005). Guar gum as a gelling agent for plant tissue culture. In Vitro Cell. Dev. Biol. Plant, 41:258-261.

Elshafei, A.A.; Esmaiel, Naglaa M.; AlDoss, A.A. and Barakat, M.N. (2011). An assessment of the cultural capabilities of clonal propagation and molecular characterization of Yucca elephantipes cultivars. J. of Medic. Plants Res., 5(13):2896-2905.

Duncan, B.D. (1955). Multiple range and multiple F test. Biometrics,11:1- 42.

Faisal, M.; Siddique, I. and Anis, M. (2006). In vitro rapid regeneration of plantlets from nodal explants of a valuable medicinal plant. Ann. Appli. Biology, 148(1):1-6.

Fira, A.; Clapa, D. and Plopa, C. (2010). New aspects regarding the micropropagation of blackberry cultivar “Thornless evergreen”. Bulletin UASVM Horticulture, 67(1):106-114.

Hassan, H.M.S.; Ali, M.A.M. and Soliman, Dina A. (2016). Effect of low-cost gelling agents and some growth regulators on micropropagation of Philodendron selloum. Plant Production, Mansoura Univ., 7(2):169-176.

Henderson, W.E. and Kinnersley, A.M. (1988). Corn starch as an alternative gelling agent for plant tissue culture media. Plant Cell Tiss. Organ Cult., 15:17-22.

Khalafalla, M.M.; Daffallai, H.M.; Abd El Latefi, E.; Agabna, E. and EL-Shemy, H.A. (2011). Establishment of an in vitro micropropagation protocol for Boscia senegalensis (Pers.) Lam. ex Poir. J. Zhejiang Univ-Sci. B. (Biomed \& Biotechnol), 12(4):303-312. 


\section{H.M.S. Hassan and M. Moubarak}

Lucyszyn, N.; Quoirin, M.; Riba, L.L.F.; Koehler, H.S. and Sierakowski, M.R. (2006). Micropropagation of "Durondeau" pear in modified-gelled medium. In Vitro Cellular \& Developmental Biology-Plant, 42:287290.

McLachlan, J.M. (1985). Industrial resources and their utilization. Plant Soil, 89:137157.

Michigan State University (1983). MSTATC Micro Computer Statistical Program, Version 2. Michigan State University, East Lansing, USA.

Moudi, K.D.; Saikia, S.P. and Borthakur, M. (2014). Effect of nodal position, seasonal varitions, shoot clump and growth regulators on micropropagation of commercially important bamboo, Bambusa nutans Wall. Ex.Munro. African J. of Biotech., 13(19):1961-1972.

Murashige, T. and Skoog, F. (1962). A revised medium for rapid growth and bioassays with tobacco tissue. Physiol. Plant, 15:473-497.

Navin, K.; Bahuguna, S.; Sati, O.P.; Sakakibara, J. and Kaiya, T. (1992). A spirostanol glycoside from Yucca aloifolia. Phytochem., 31:706-707.
Romano, A. and Gonçalves, S. (2005). Locust bean gum (LBG) as a gelling agent for plant tissue culture media. Scientia Horticulturae, 106(1):129-134.

Seyyed, R.S.; Kaviani, B. and Dehkaei, N.P. (2013). The effect of different concentrations of NAA and BAP on micropropagation of Alstroemeria. European J. of Experimental Biology, 3(5):133-136.

Shaheen, M.A.; Hamo, B.T. and Al-Johane, A.S. (2009). Enhancement of shoot tip multiplication and rooting formation in micropropagation of Yucca elephantipes under different concentrations of BA and IBA. King Abdulaziz J., 20(1):3-22.

Soliman, D.A.; Hassan, H.M.S. and Ali, M.A.M. (2016). Effect of some growth regulators and gelling agent on micropropagation of Codiaeum varigatum. Sinai J. of Applied Sci., 5(2):173-186.

Windholz, M.; Budavari, S.; Blumetti, R.F. and Otterbein, E.S. (1983). The Merck Index: An Encyclopedia of Chemicals, Drugs and Biologicals, $3^{\text {rd }}$ ed. Rahway, NJ: Merck and Co. Inc., New Jersey, USA.

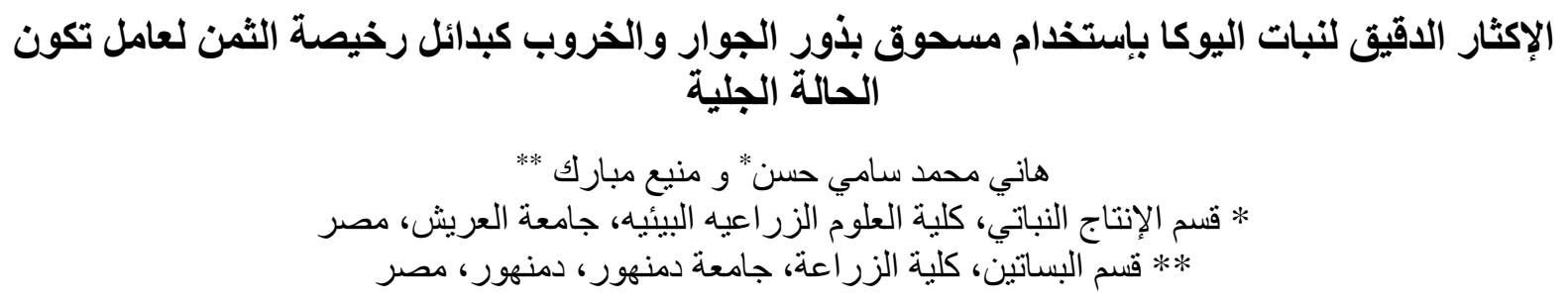

تهدف هذه الدر اسة إلى تحديد أنسب نوع و تركيز من منظمات النمو و البحث عن بدائل للأجار رخيصة ومتاحة

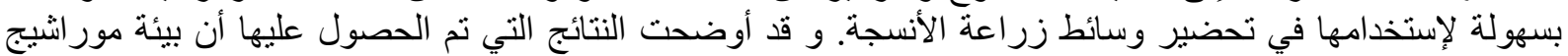

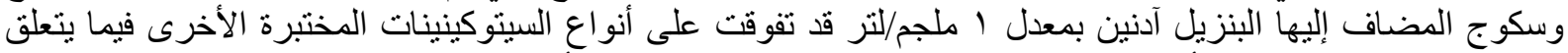

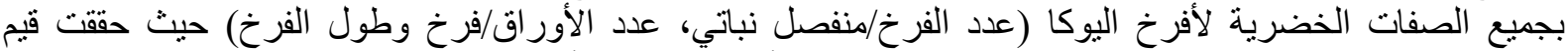

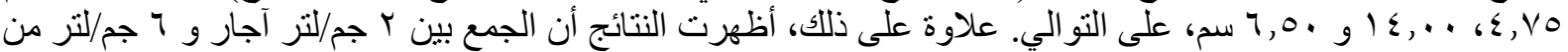

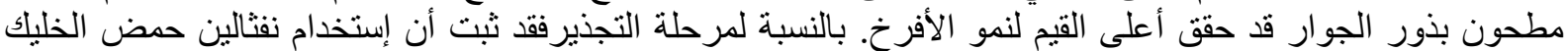

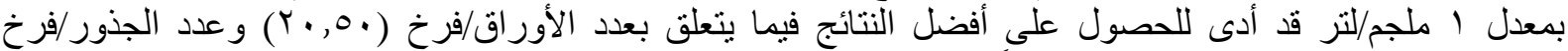

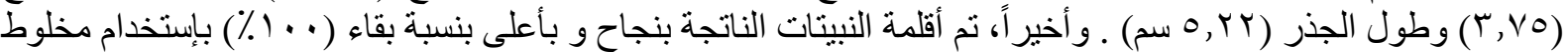
من الرمل و البيتموس بنسب حجمية منساوية. 